\title{
PENGARUH KREDIT TERHADAP PENDAPATAN PADA PT. BANK BENGKULU
}

\author{
Rinto Noviantoro, Iwin Juita \\ Fakultas Ekonomi Universitas Dehasen Bengkulu \\ rintonoviantoro@yahoo.co.id
}

\begin{abstract}
ABSTRAK
Rinto Noviantoro, Iwin Juita; Penelitian ini bertujuan untuk menganalisis pengaruh kredit konsumsi, kredit modal kerja, kredit investasi terhadap pendapatan pada PT. Bank Bengkulu. Data yang digunakan adalah data sekunder yang berasal dari laporan keuangan tahunan PT. Bank Bengkulu periode tahun 2010 sampai tahun 2017. Metode pengujian data menggunakan analisis regresi linear berganda, analisis korelasi, koefisien determinasi ( $\mathrm{R}^{2}$ ), dengan pengujian hipotesis statistik t (uji t)dan uji statistik F (uji F).

Hasil penelitian dengan menggunakan uji regresi linear berganda memperoleh persamaan regresi $\mathrm{Y}=470287.976-0.035 \mathrm{X}_{1}-20.430 \mathrm{X}_{2}+46.218 \mathrm{X}_{3}$. Artinya, jika kredit konsumsi, kredit modal kerja, kredit investasi nilainya 0, maka pendapatan sebesar Rp. 470.287. Jika terjadi penurunan kredit konsumsi sebesar Rp. 1, maka nilai pendapatan menurun sebesar Rp. -0.035,- jika kredit modal kerja menurun Rp 1,- maka pendapatan akan menurun sebesar Rp.-0 20.430,- dan jika kredit investasi meningkat sebesar Rp. 1,- maka pendapatan akan meningkat sebesar Rp. 46.218.
\end{abstract}

\section{ABSTRACT}

Rinto Noviantoro, Iwin Juita; This study aims to analyze the effect of consumption credit, working capital credit, and investment credit on revenue at PT. Bank Bengkulu. The data used are secondary data derived from the annual financial statements of PT. Bank Bengkulu from 2010 to 2017. Data testing methods used is multiple linear regression analysis, correlation analysis, determination coefficient $\left(R^{2}\right)$, by testing the statistical hypothesis $t$ ( $t$ test) and $F$ statistical test ( $F$ test). The results of the study using multiple linear regression test obtained the regression equation $Y=470287,976-0.035 X 1-20,430 X 2+46,218 X 3$. That is, if the consumption credit, working capital credit, and investment credit is worth 0 , then the revenue is $R p$. 470,287. If there is a decrease in consumption credit of $R p .1$, then the value of revenue decreases by $R p$. 0,035, - if the working capital loan decreases by Rp. 1, then the revenue will decrease by Rp. 0 20,430, - and if the investment credit increases by $R p .1$, - then the revenue will increase by $R p .46,218$. The test results of the coefficient of determination $\left(R^{2}\right)$ indicate that the credit given has an effect of $20.5 \%$ on revenue. While $79.5 \%$ is influenced by other factors not examined. The results of partial hypothesis testing ( $t$ test) state that consumption credit has a negative and not significant effect on revenue with a significant value of 0.820 and $t$ count of $-0.244<2.446 t$ table. The testing results of working capital loans show a negative results and not significant effect on revenue with a significance value of 0.379 and $t$ count of $-0.988<2.446 t$ table. The results of the investment credit test show that the results have a positive and not significant effect on revenue with a significance value of 0.371 and a value of $t$ count $-1.008<2.446 t$ table. While the simultaneous test results show that consumption credit, working capital credit, and investment credit have no significant effect on revenue with a significance level of 0.796 and a calculated $F$ count of $0.344<F$ table of 5.786.

\section{Keywords: Credit, Revenue, Bank.}

\section{LATAR BELAKANG}

Bank adalah lembaga keuangan yang kegiatan utamanya menghimpun dana dari masyarakat dan menyalurkan kembali dana tersebut ke masyarakat dalam bentuk kredit dan bentuk lainnya dalam rangka meningkatkan taraf hidup rakyat banyak (Kasmir, 2014:12). Bank merupakan salah satu lembaga keuangan yang mencari laba dengan cara menyalurkan kredit kepada masyarakat.

Kualitas kredit akan menentukan kelangsungan hidup bank, menyadari betapa pentingnya masalah kualitas kredit sehingga berbagai regulasi dibidang perkreditan diterbitkan oleh Pemerintah, Bank Indonesia dan Otoritas Jasa Keuangan, semua regulasi itu dimaksudkan untuk mengelola dan mengendalikan resiko kredit agar dapat diminimalkan sehingga kelangsungan usaha bank tidak terganggu. Kredit yang bermasalah akan mempengaruhi tingkat penyaluran kredit dan pendapatan.

Oleh karena itu, dalam pelaksanaanya bank harus berpegang tegu pada azaz-azaz perkreditan yang sehat. Untuk meminimalkan resiko terjadinya kredit bermasalah, maka sebelum bank memberikan kredit bank harus melakukan analisis terhadap data-data debitur, analisis kredit penting untuk dilakukan supaya bank dapat mengkonfirmasi kebenaran data-data yang diajukan oleh debitur sehingga pemberian 
kredit kepada debitur layak untuk dilakukan atau tidak, analisis kredit dikenal dengan prinsip 5 C, yaitu Caracter, Capacity, Capital, Collateral, Condition of Economy (Fahmi, 2014:76).

Besarnya tingkat kredit yang disalurkan dengan kualitas yang baik akan berdampak terhadap pendapatan bank, semakin besar kredit yang disalurkan maka kemungkinan untuk memproleh pendapatan juga besar. Pendapatan bank merupakan hasil langsung dari kegiatan operasional bank, salah satunya adalah kegiatan penyaluran kredit.

Semakin tingginya pendapatan yang diperoleh oleh bank, hal itu menunjukkan kinerja manajemen bank berhasil dalam mengelolah dana yang di himpun dari masyarakat. Selain itu, pendapatan yang tinggi tentu akan membuat bank memperoleh keutungan yang besar dan bank tersebut dapat terus tumbuh dan berkembang dalam melayani kebutuhan keuangan masyarakat.

PT. Bank Bengkulu merupakan salah satu Badan Usaha Milik Daerah (BUMD) Provinsi Bengkulu yang terus tumbuh dan berkembang dalam melayani kebutuhan keuangan masyarakat di Provinsi Bengkulu khususnya. Sederet prestasi yang membanggakan berhasil diraih oleh PT. Bank Bengkulu, hal ini tentu dinilai dari kinerja nya yang baik. Untuk terus tumbuh dan berkembang dalam melayani kebutuhan keuangan masyarakat, para pemegang saham PT. Bank Bengkulu terus meningkatkan setoran modal sahamnya. Selain itu, jika dilihat dari komposisi kredit yang diberikan oleh PT. Bank Bengkulu terus mengalami peningkatan setiap tahunnya, hal ini tentu bedampak positif terhadap kinerja bank karena dengan meningkatnya pemberian kredit tersebut berdampak secara langsung terhadap perolehan pendapatan bank. Berikut data kredit yang diberikan serta pendapatan PT. Bank Bengkulu.

Tabel 1. Komposisi Kredit Yang Diberikan PT.Bank Bengkulu (Dalam Jutan Rupiah)

\begin{tabular}{|l|l|l|l|l|}
\hline \multicolumn{1}{|c|}{ Tahun } & $\begin{array}{c}\text { Kredit } \\
\text { Konsumsi }\end{array}$ & \multicolumn{1}{c|}{ Kredit Modal Kerja } & $\begin{array}{c}\text { Kredit } \\
\text { Investasi }\end{array}$ & \multicolumn{1}{c|}{ jumlah } \\
\hline 2010 & 998.175 & 29.038 & 8.509 & 1.035 .722 \\
\hline 2011 & 1.298 .455 & 12.261 & 9.458 & 1.320 .174 \\
\hline 2012 & 0 & 0 & 0 & 0 \\
\hline 2013 & 0 & 0 & 0 & 0 \\
\hline 2014 & 59.947 & 41.564 & 19.971 & 121.482 \\
\hline 2015 & 3.211 .054 & 55.970 & 27.042 & 3.294 .066 \\
\hline 2016 & 0 & 0 & 0 & $\mathbf{0}$ \\
\hline 2017 & 0 & 0 & 0 & $\mathbf{0}$ \\
\hline Rata-rata & 695.954 & 17.354 & 8.123 & 721.431 \\
\hline Total & 5.567 .631$. & 138.833 & 64.980 & 203.813 \\
\hline
\end{tabular}

Sumber : Laporan Keuangan PT. Bank Bengkulu, Data Diolah, 2018.

Tabel 2. Pendapatan PT. Bank Bengkulu (Dalam Jutan Rupiah)

\begin{tabular}{|l|l|l|l|l|}
\hline Tahun & \multicolumn{1}{|c|}{$\begin{array}{c}\text { Pendapatan } \\
\text { Operasional }\end{array}$} & $\begin{array}{c}\text { Pendapatan } \\
\text { Operasional } \\
\text { Lainnya }\end{array}$ & $\begin{array}{c}\text { Pendapatan Non } \\
\text { Operasional }\end{array}$ & \multicolumn{1}{|c|}{ Jumlah } \\
\hline 2010 & 298.711 & 16.474 & 8.532 & 323.717 \\
\hline 2011 & 246.831 & 33.507 & 13.236 & 293.574 \\
\hline 2012 & 307.958 & 44.930 & 2.855 & 355.743 \\
\hline 3013 & 417.212 & 37.906 & 0 & 455.118 \\
\hline 2014 & 466.545 & 38.060 & 14.374 & 518.979 \\
\hline 2015 & 584.205 & 43.880 & 29.410 & 657.495 \\
\hline 2016 & 652.927 & 31.674 & 2.919 & 687.520 \\
\hline 2017 & 693.592 & 28.686 & 13.799 & 736.077 \\
\hline rata-rata & 68.583 .043 .699 & 6.275 .984 .477 & 2.729 .142 .894 & 77.588 .171 .070 \\
\hline Total & 548.664 .349 .590 & 50.207 .875 .813 & 21.833 .143 .151 & 620.705 .368 .554 \\
\hline
\end{tabular}

Sumber : Laporan Keuangan PT. Bank Bengkulu, Data Diolah, 2018.

Jika dilihat dari tabel di atas, kredit yang diberikan oleh PT. Bank Bengkulu terus meningkat disetiap tahunnya, hal itu diikuti juga oleh tingkat pendapatan yang terus meningkat. Secara langsung hal ini menunjukkan betapa besarnya pengaruh kredit yang diberikan oleh bank terhadap tingkat pendapatan yang diperoleh. Berdasarkan latar belakang yang telah diuraikan di atas, penulis tertarik untuk meneliti pengaruh kredit yang diberikan terhadap pendapatan dengan mengangkat judul "Analisis Pengaruh Kredit Yang Diberikan terhadap Pendapatan Pada PT. Bank Bengkulu" 


\section{Landasan Teori \\ Bank}

Secara sederhana bank dapat diartikan sebagai lembaga keuangan yang kegiatan utamanya menghimpun dana dari masyarakat dan menyalurkannya kembali kepada masyarakat serta memberikan jasa bank lainnya (Kasmir, 2014:12). Serta Undang-Undang No.10 tahun 1998 menyatakan bahwa bank adalah badan usaha yang menghimpun dana dari masyarakat dalam bentuk simpanan dan menyalurkannya kepada masyarakat dalam bentuk kredit dan atau bentuk-bentuk lainya dalam rangka meningkatkan taraf hidup masyarakat.

\section{Fungsi dan Tujuan Bank}

Secara umum fungsi utama bank adalah menghimpun dana dari masyarakat dan menyalurkan kembali kepada masyarakat untuk berbagai tujuan atau sebagai perantara keuangan (financial intermediary). Secara lebih spesifik bank dapat sebagai Agent of Trust, Agent of Development, dan Agent of Service (Budisusanto dan Nuritomo, 2013:9)

1. Agent of Trust

Dasar utama kegiatan perbankan adalah kepercayaan (trust), baik dalam hal menghimpun dana maupun penyaluran dana. Masyarakat mau menitipkan dananya di bank apabila dilandasi adanya unsur kepercayaan. Masyarakat percaya bahwa uangnya tidak akan disalahgunakan oleh bank, uangnya akan dikelola dengan baik, bank tidak akan bangkrut, dan pada saat yang telah dijanjikan simpanan tersebut dapat ditarik kembali dari bank. Pihak bank sendiri akan mau menempatkan atau menyalurkan dananya pada debitur atau masyarakat apabila dilandasi adanya unsur kepercayaan. Pihak bank percaya bahwa debitur tidak akan menyalahgunakan pinjamannya, debitur akan mengelola dana pinjaman saat jatuh tempo, dan debitur mempunyai niat baik untuk mengembalikan pinjaman beserta kewajiban lainnya pada saat jatuh tempo.

2. Agent of Development

Kegiatan perekonomian masyarakat di sektor moneter dan di sektor riil tidak dapat dipisahkan. Kedua sektor tersebut selalu berinteraksi dan saling mempengaruhi. Sektor riil tidak akan dapat berkinerja dengan baik apabila sektor moneter tidak bekerja dengan baik. Kegiatan bank berupa penghimpunan dan penyaluran dana sangat diperlukan bagi lancarnya kegiatan perekonomian di sektor riil. Kegiatan bank tersebut memungkinkan masyarakat melakukan kegiatan investasi, kegiatan distribusi, serta kegiatan konsumsi barang dan jasa, mengingat bahwa kegiatan investasidistribusi-konsumsi tidak dapat dilepaskan dari adanya penggunaan uang. Kelancaran kegiatan investasi, distribusi, dan konsumsi ini tidak lain adalah kegiatan pembangunan perekonomian suatu masyarakat.

3. Agent of Service

Selain melakukan kegiatan penghimpunan dan penyaluran dana, bank juga memberikan penawaran jasa perbankan yang lain kepada masyarakat. Jasa ditawarkan bank ini erat kaitannya dengan kegiatan perekonomian secara luas. Jasa ini antara lain dapat berupa jasa pengiriman uang, penitipan barang berharga, pemberian jaminan bank, dan penyelesaian tagihan. Sedangkan tujuan bank dalam Undang-undang No. 10 tahun 1998 tentang perbankan adalah untuk menunjang pelaksanaan pembangunan nasional dalam rangka meningkatkan pemerataan, pertumbuhan ekonomi, dan stabilitas nasional ke arah peningkatan kesejahteraan rakyat banyak.

\section{Kredit}

Kredit merupakan pemberian fasilitas pinjaman kepada nasabah, baik berupa fasilitas pinjaman tunai maupun pinjaman non tunai. Pemberian kredit secara tunai merupakan suatu bentuk usaha yang dapat dilakukan oleh sebuah bank. Berdasarkan Undang-Undang No 10 Tahun 1998 tentang Perubahan atas Undang-Undang No 7 Tahun 1992 tentang Perbankan, yang dimaksud dengan kredit adalah penyediaan uang atau tagihan yang dapat dipersamakan dengan itu, berdasarkan persetujuan atau kesepakatan pinjam-meminjam antara bank dengan pihak lain yang mewajibkan pihak peminjam untuk melunasi utangnya setelah jangkan waktu tertentu dengan pemberian bunga.

\section{Unsur-Unsur Kredit}

Adapun unsur-unsur dalam pemberian suatu fasilitas kredit adalah sebagai berikut (Kasmir, 2014:114):

1. Kepercayaan

Kepercayaan merupakan suatu keyakinan bagi kreditur bahwa kredit yang diberikan (baik berupak uang, barang, jasa) benar-benar diterima kembali di masa yang akan datang sesuai jangka waktu kredit. Kepercayaan diberikan oleh bank sebagai dasar utama yang melandasi mengapa kredit berani untuk diberikan. 
2. Kesepakatan

Disamping kepercayaan, didalam kredit juga mengandung unsur kesepakatan antara kreditr dengan debitur. Kesepakatan ini dituangkan dalam perjanjian di mana masing-masing pihak menandatangani hak dan kewajiban masing-masing.

3. Jangka waktu Jangka waktu mencakup pengembalian kredit yang telah disepakati. Jangka waktu tersebut bisa berbentuk jangka pendek maupun jangka panjang. Untuki kondisi tertentu, jangka waktu ini bisa saja diperpanjang sesuai kebutuhan.

4. Risiko

Akibat adanya tenggang waktu, pengembalian kredit akan memungkinkan suatu resiko tidak tertagihnya atau macet. Risiko ini menajdi tanggungan bank akibat dari faktor kesengajaan atau tidak kesengajaan dari nasabah sehingga nasabah tidak dapat melunasi hutangnya.

5. Balas jasa

Bagi bank, balas jasa merupakan keuntungan atau pedapatan atas pemberian suatu kredit. Balas jasa ini bisa berbentuk bunga dan hasil pembebanan biaya administrasi kepada nasabah.

\section{Jenis-Jenis Kredit}

Beragamnya jenis usaha menyebabkan beragam pula kebutuhan akan dana, kebutuha dana yang beragam menyebabkan jenis juga menjadi beragam, dalam praktiknya kredit yang diberikan bank umum dan bank perkreditan rakyat kepada masyarakt terdiri dari berbagai jenis, secara umum jenis-jenis kredit dapat dilihat dari berbagai segi sebagai berikut (Taswan, 2017:120) :

1. Dilihat dari segi kegunaan

a. Kredit investasi

Kredit investasi merupakan kredit jangka panjang yang biasanya digunakan untuk keperluan perluasan usaha atau membangun proyek atau keperluan rehabilitas.

b. Kredit modal kerja

Kredit modal kerja merupakan kredit yang digunakan untuk keperluan meningkatkan produksi dalam operasionalnya.

c. Kredit konsumsi

Kredit konsumsi merupakan kredit untuk keperluan konsumsi pribadi. Dalam kredit ini tidak ada pertambahan barang dan jasa yang dihasilkan, karena memang untuk digunakan atau dipakai oleh seseorang atau badan usaha.

2. Dilihat dari segi tujuan

a. Kredit produktif

Kredit yang digunakan untuk peningkatan usaha atau produksi atau investasi. Kredit ini diberikan untuk menghasilkan barang atau jasa.

b. Kredit perdagangan

Kredit perdagangan yang diberikan kepada pedagang dan digunakan untuk membiayai aktivitas perdagangan seperti untuk membeli barang dagangan yang pembayarannya diharapkan dari hasil penjuyalan barang dagangan tersebut.

3. Dilihat dari segi jangka waktu

a. Kredit jangka pendek

Kredit jangka pendek berjangka waktu maksimal satu tahun dan biasanya digunakan untuk keperluan modal kerja.

b. Kredit jangka menengah

Kredit jangkan menengah mempunyai waktu minimal satu tahun dan maksimal tiga tahun dan biasanya kredit ini digunakan untuk melakukan invesatsi.

c. Kredit jangka panjang

Kredit jangka panjang merupakan kredit yang masa pengembaliannya paling panjang biasanya lima tahun atau lebih.

4. Dilihat dari segi jaminan

a. Kredit dengan jaminan

Kredit dengan jaminan merupaka kredit yang diberikan dengan suatu jaminan. Jaminan tersebut dapat berbentuk barang berwujud atau tidka berwujud atau jaminan orang dan nilai jaminan tersebut harus di atas nilai kredit yang diterima debitur.

b. Kredit tanpa jaminan

Kredit tanpa jaminan merupaka kredit yang diberikan tanpa jaminan barang atau oran tertentu. Jenis kredit ini diberikan dengan melihat prospek usaha, karakter serta loyalitas atau nama baik si calon debitur selama berhubungan dengan bank atau pihak lain. 
5. Dilihat dari segi sektor usaha

Kredit ini diberikan dengan melihat sektor usaha yang dimiliki debitur, seperti pertanian, peternakan, industry, pertambangan, pendidikan, profesi, perumahan dan sektor usaha lainnya.

\section{Kerangka Analisis}

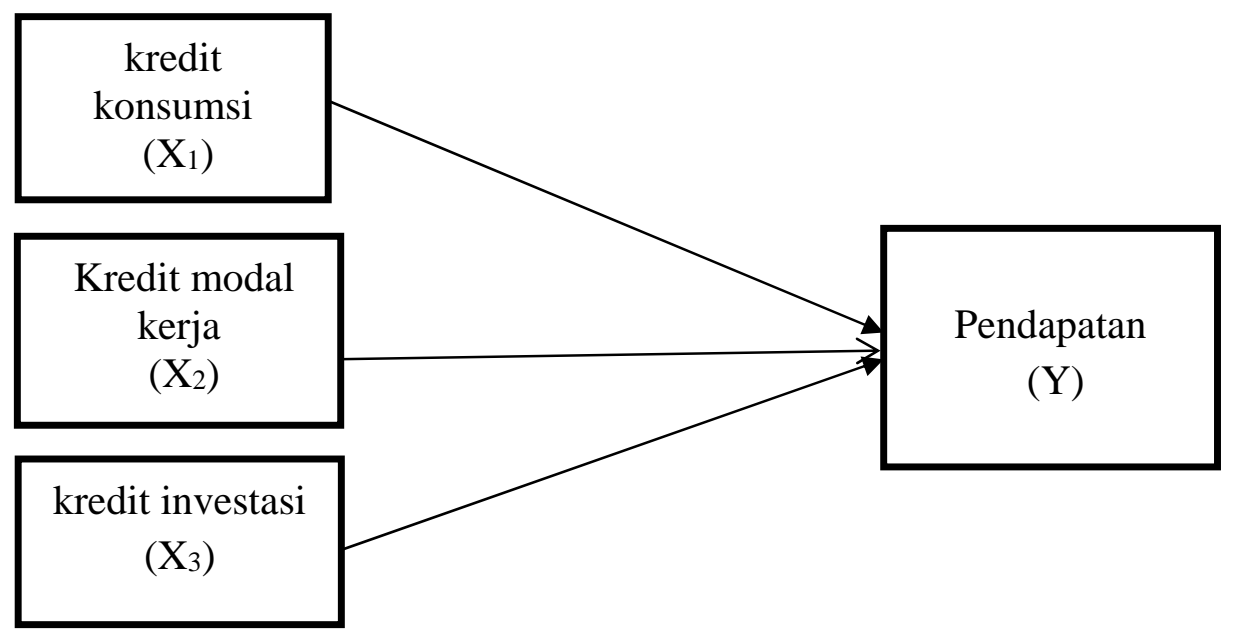

Gambar 1. Kerangka Analisis

\section{Hipotesis Penelitian}

Berdasarkan tujuan penelitian, rumusan masalah yang diajukan, dan kajian teori yang dikemukakan pada bab-bab sebelumnya, maka hipotesis pada penelitian ini adalah sebagai berikut :

$\mathrm{H}_{1}$ : Diduga kredit konsumsi secara parsial berpengaruh positif terhadap pendapatan pada PT. Bank Bengkulu tahun 2010 sampai tahun 2017.

$\mathrm{H}_{2}$ : Diduga kredit modal kerja secara parsial berpengaruh positif terhadap pendapatan pada PT. Bank Bengkulu tahun 2010 sampai tahun 2017.

$\mathrm{H}_{3}$ : Diduga kredit investasi secara parsial berpengaruh positif terhadap pendapatan pada PT. Bank Bengkulu tahun 2010 sampai tahun 2017.

$\mathrm{H}_{4}$ : $\quad$ Diduga kredit konsumsi, kredit modal kerja, kredit investasi secara simultan berpengaruh positif terhadap pendapatan pada PT. Bank Bengkulu tahun 2010 sampai tahun 2017.

\section{METODE PENELITIAN}

Sesuai dengan tujuan penelitian ini yaitu untuk melihat pengaruh kredit yang diberikan terhadap pendapatan dengan menggunakan data laporan keuangan tahun 2010 sampai tahun 2017. Maka, penelitian ini menggunakan pendekatan kuantitatif yang menggunakan data sekunder berupa laporan keuangan PT. Bank Bengkulu. Penelitian kuantitatif adalah suatu proses menemukan pengetahuan yang menggunakan data berupa angka sebagai alat menganalisis keterangan mengenai apa yang ingin diketahui (Kasiram, 2008:149). Data sekunder adalah informasi tangan kedua yang telah dikumpulkan oleh beberapa orang (organisasi) untuk tujuan tertentu dan tersedia untuk berbagai penelitian (Riadi, 2016:48)

\section{Metode Analisis}

Metode analisis yang digunakan dalam penelitian ini adalah regresi linear sederhana. Analisis regresi linear sederhana dilakukan dengan menggunakan program SPSS Versi 17 For Windows.

1. Analisis Regresi Linear Berganda

Analisis regresi linear sederhana digunakan untuk menguji pengaruh dari variabel independen kredit yang diberikan $\left(\mathrm{X}_{1}\right),\left(\mathrm{X}_{2}\right),\left(\mathrm{X}_{3}\right)$ sedangkan sebagai variabel dependen adalah pendapatan $(\mathrm{Y})$. Bentuk persamaan regresi linear berganda adalah (Riadi, 2016:147) :

$\mathrm{Y}=\mathrm{a}+\mathrm{b}_{1} \mathrm{X}_{1}+\mathrm{b}_{2} \mathrm{X}_{2}+\mathrm{b}_{3} \mathrm{X}_{3}$

$\mathrm{Y} \quad$ : Pendapatan

a : Konstanta

b : Koefisien regresi

$\mathrm{X}_{1}, \mathrm{X}_{2}, \mathrm{X}_{3} \quad$ : Kredit konsumsi, kredit modal kerja, kredit investasi 


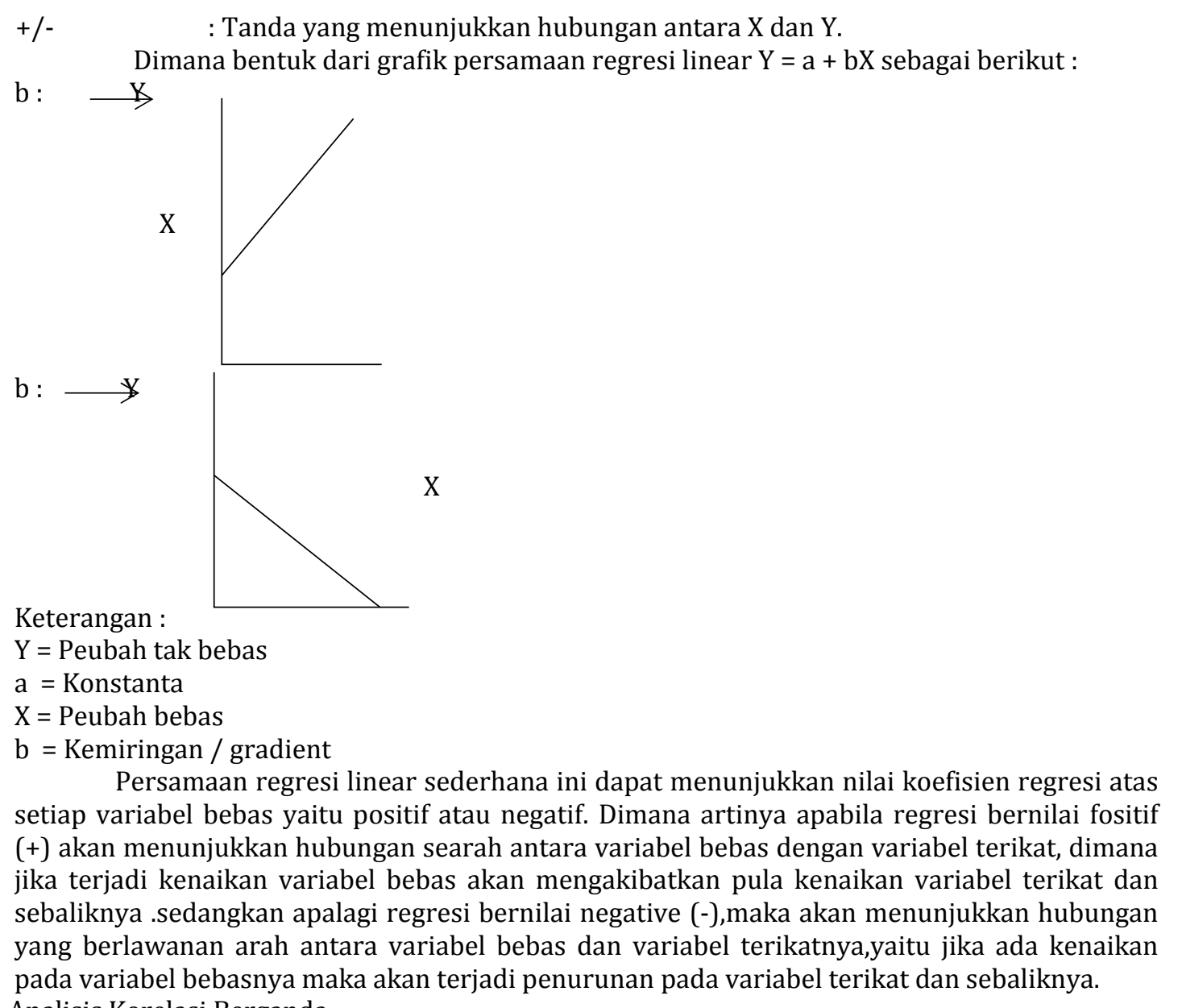

2. Analisis Korelasi Berganda

Analisis korelasi berganda berguna untuk menentukan suatu besaran yang menyatakan seberapa kuat hubungan suatu variabel dengan variabel lain. Untuk kekuatan hubungan, nilai koefesien korelasi berada antara -1 dan 1 . Untuk bentuk/arah hubungan, nilai koefisien korelasi dinyatakan dalam positif $(+)$ dan negatif $(-)$, atau $(-1 \leq r \leq+1)$, artinya jika:

$r=1$, hubungan $X$ dan $Y$ sempurna dan positif (mendekati 1, hubungan sangat kuat dan positif)

$r=-1$, hubungan $X$ dan $Y$ sempurna dan negatif (mendekati -1, hubungan sangat kuat dan negatif)

$\mathrm{r}=0$, hubungan $\mathrm{X}$ dan $Y$ lemah sekali atau tidak ada hubungan.

Penentuan koefesien korelasi ganda tiga prediktor (r) dalam penelitian ini menggunakan rumus berikut:

$\operatorname{Ry}(1,2,3)=\frac{\mathrm{b}_{1} \sum \mathrm{X}_{1} \mathrm{Y}+\mathrm{b}_{2} \sum \mathrm{X}_{2} \mathrm{Y}+\mathrm{b}_{3} \sum \mathrm{X}_{3} \mathrm{Y}}{\sum \mathrm{Y}^{2}}$

Sumber: Sugiyono,2017:286

Tabel 3. Pedoman Interprestasi Koefisien Korelasi

\begin{tabular}{|l|l|}
\hline Interval Koefisien & Tingkat Hubungan \\
\hline $0,80-1,000$ & Sangat Kuat \\
\hline $0,60-0799$ & Kuat \\
\hline $0,40-0,599$ & Cukup Kuat \\
\hline $0,20-0,399$ & Rendah \\
\hline $0,00-0,199$ & Sangat Rendah \\
\hline
\end{tabular}

3. Analisis Koefisien Determinasi

Untuk mengetahui besarnya pengaruh variabel $\mathrm{X}_{1}, \mathrm{X}_{2}$, dan $\mathrm{X}_{3}$ terhadap variabel $\mathrm{Y}$ adalah dengan menggunakan teknik analisis koefisien determinasi (kd), dimana penggunaan koefisien determinasi dinyatakan dalam presentase, dengan rumus sebagai berikut:

$\mathrm{KD}=\mathrm{r}^{2} \mathrm{x} 100 \%$ dengan asumsi $0<\mathrm{r}^{2}<1$ (Sugiyono 2017:286) 
Jika $\mathrm{r}^{2}$ diperoleh dari hasil perhitungan semakin besar atau mendekati 1 maka dapat dikatakan bahwa peranan dari variabel X terhadap variabel $Y$ akan semakin besar, ini berarti model digunakan semakin kuat untuk menerangkan variabel Y-nya. Sebaliknya jika $\mathrm{r}^{2}$ semakin kecil atau mendekati 0 maka dapat dikatakan peranan variabel $\mathrm{X}$ terhadap variabel Y semakin kecil. Hal ini berarti model yang digunakan semakin lemah untuk menerangkan variasi variabel terikatnya. Secara umum dapat dikatakan bahwa koefisien determinasi $r^{2}$ berada diantara 0 dan 1.

4. Uji Hipotesis

Pengujian hipotesis menggunakan uji statistik $\mathrm{t}$ (uji t). Uji $\mathrm{t}$ digunakan untuk melihat pengaruh antara variabel kredit terhadap variabel pendapatan. Langkah dalam menguji hipotesis dengan menggunakan uji t adalah sebagai berikut (Hasan, 2012:255) :

a. Menghitung uji t

Rumus yang digunakan untuk menghitung uji t sebagai berikut :

thitung $=r \frac{\sqrt{n-Z}}{\sqrt{1-r^{2}}}$

Keterangan :

$\mathrm{r}=$ Koefisien Korelasi

$\mathrm{n}=$ Jumlah Data

b. Merumuskan hipotesis

$\mathrm{HO}_{1}$ : Kredit konsumsi tidak mempunyai pengaruh yang positif terhadap pendapatan pada PT. Bank Bengkulu.

$\mathrm{HO}_{2}$ : $\quad$ Kredit modal kerja tidak mempunyai pengaruh yang positif terhadap pendapatan pada PT. Bank Bengkulu.

$\mathrm{HO}_{3}$ : $\quad$ Kredit investasi tidak mempunyai pengaruh yang positif terhadap pendapatan pada PT. Bank Bengkulu.

Ha1: Kredit konsumsi mempunyai pengaruh yang positif terhadap pendapatan pada PT. Bank Bengkulu.

$\mathrm{Ha}_{2}$ : Kredit modal kerja mempunyai pengaruh yang positif terhadap pendapatan pada PT. Bank Bengkulu.

$\mathrm{Ha}_{3}$ : Kredit investasi mempunyai pengaruh yang positif terhadap pendapatan pada PT. Bank Bengkulu.

c. Kriteria pengujian

(1) Jika nilai signifikansi $>0,05$ dan nilai thitung $<t_{\text {tabel, maka H0 diterima }}$ dan Ha ditolak. Artinya, tidak terdapat pengaruh yang positif antara kredit terhadap pendapatan pada PT. Bank Bengkulu.

(2) Jika nilai signifikansi $<0,05$, dan nilai thitung $>$ tabel, maka Ha diterima dan $\mathrm{H} 0$ ditolak. Artinya, terdapat pengaruh yang positif antara kredit terhadap pendapatan pada PT. Bank Bengkulu.

5. Pengujian Hipotesis Secara Simultan

Uji $\mathrm{F}$ adalah pengujian terhadap koefisisen regresi secara simultan, pengujian ini dilakukan untuk mengetahui pengaruh semua variabel independen yang terdapat didalam model secara bersama-sama (simultan) terhadap variabel dependen.

Menurut Sugiyono (2017:235), menggunakan rumus:

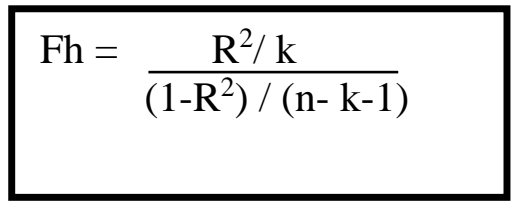

Keterangan:

$\mathrm{R}^{2}=$ Koefisien determinasi

$\mathrm{k}=$ Jumlah variabel Independen

$\mathrm{n}=$ Jumlah data

$\mathrm{F}$ hasil perhitungan ini dibandingkan $\mathrm{F}_{\text {tabel }}$ yang di peroleh dengan mengunakan tingkat resiko atau signifikan level 5\% dengan kriteria sebagai berikut:

$\mathrm{H}_{\mathrm{a}}$ diterima jika $\mathrm{F}_{\text {hitung }}>\mathrm{F}_{\text {tabel }}$ atau nilai sig $<\alpha$

$\mathrm{H}_{\mathrm{o}}$ ditolak jika $\mathrm{F}_{\text {hitung }}<\mathrm{F}_{\text {tabel }}$ atau nilai sig $>\alpha$ 
Jika terjadi penerimaan $\mathrm{H}_{\mathrm{o}}$, maka dapat diartikan tidak berpengaruh signifikan model regresi berganda yang diperoleh sehingga mengakibatkan tidak signifikan pula.Pengaruh dari variabel-variabel bebas.

Adapun yang menjadi hipotesis nol $\mathrm{H}_{\mathrm{o}}$ dalam penelitian ini adalah sebagai berikut:

$\mathrm{H}_{\mathrm{o}}: \beta_{1}=\beta_{2}=\beta_{3}=0$ : tidak berpengaruh signifikan

$\mathrm{H}_{\mathrm{a}}: \beta_{1} \neq \beta_{2} \neq \beta_{3} \neq 0$ : terdapat pengaruh yang signifikan

Dalam melakukan analisis dan pengolahan data menggunakan bantuan komputer dengan menggunakan program Sofware Statistic.

\section{HASIL PENELITIAN DAN PEMBAHASAN \\ Pendapatan PT. Bank Bengkulu}

Pendapatan merupakan salah satu ukuran kinerja bank.Pendapatan diperoleh dari hasil operasional bank, baik pendapatan dari aktivitas operasional maupun pendapatan dari aktivitas non operasional.Berikut pendapatan yang diperoleh oleh PT. Bank Bengkulu selama periode tahun 2010 sampai tahun 2017.

Tabel 4. Pendapatan PT. Bank Bengkulu (Dalam Jutan Rupiah)

\begin{tabular}{|c|c|c|c|c|}
\hline Tahun & $\begin{array}{c}\text { Pendapatan } \\
\text { Operasional }\end{array}$ & $\begin{array}{c}\text { Pendapatan } \\
\text { Operasional Lainnya }\end{array}$ & $\begin{array}{c}\text { Pendapatan Non } \\
\text { Operasional }\end{array}$ & Jumlah \\
\hline 2010 & 298.711 & 16.474 & 8.532 & 323.717 \\
\hline 2011 & 246.831 & 33.507 & 13.236 & 293.574 \\
\hline 2012 & 307.958 & 44.930 & 2.855 & 355.743 \\
\hline 3013 & 417.212 & 37.906 & 0 & 455.118 \\
\hline 2014 & 466.545 & 38.060 & 14.374 & 518.979 \\
\hline 2015 & 584.205 & 43.880 & 29.410 & 657.495 \\
\hline 2016 & 652.927 & 31.674 & 2.919 & 687.520 \\
\hline 2017 & 693.592 & 28.686 & 13.799 & 736.077 \\
\hline rata-rata & 68.583 .043 .699 & 6.275 .984 .477 & 2.729 .142 .894 & 77.588 .171 .070 \\
\hline Total & 548.664 .349 .590 & 50.207 .875 .813 & 21.833 .143 .151 & 620.705 .368 .554 \\
\hline
\end{tabular}

Sumber : Laporan Keuangan, Data Diolah, 2018.

Berdasarkan tabel di atas, pendapatan operasional dari tahun 2010 sampai tahun 2017 mengalami trend yang positif dengan total pendapatan operasional sebesar Rp. 548.664.349.590 dengan rerata pendapatan operasional yang diterima dari tahun 2010 sampai tahun 2017 adalah sebesar Rp. 68.582.043.699,-. Sedangkan pendapatan operasional lainnya juga berkontribusi cukup besar dengan rerata penerimaan selama tahun 2010 sampai 2017 adalah sebesar Rp. 6.275.984.477,- dan total penerimaan pendapatan operasional lainnya adalah sebesar Rp. 50.207.875.813,-- Selain pendapatan operasional dan pendapatan operasional lainnya, pendpatan non operasional juga membrikan kontrubsi kepada PT. Bank Bengkulu. Rerata pendapatan non operasil selama tahun 2010 sampai 2017 adalah sebesar Rp. 2.729.142.894 dengan total keseluruahn tahun 2010 sampai tahun 2017 adalah sebagai berikut Rp. 21.833.143.151,--

\section{Hasil Uji Regresi Linear Berganda}

Berdasarkan tabel diatas mengenai kredit konsumsi, kredit modal kerja, dan kredit investai, serta pendapatan PT. Bank Bengkulu. Hasil pengujian regresi linear berganda menunjukkan sebagai berikut :

\section{Tabel 5. Hasil Uji Regresi Linear Berganda}

Coefficients

\begin{tabular}{|ll|l|l|l|l|l|l|}
\hline \multicolumn{2}{|l|}{ Model } & \multicolumn{2}{|l|}{ Koefisien tidak standar } & Koefisien standar & \multicolumn{3}{l|}{$\mid$} \\
\cline { 2 - 7 } & $\mathrm{B}$ & Std. Error & Beta & $\mathrm{T}$ & Sig. \\
\hline 1 & (Konstanta) & 470287.976 & 128727.036 & & 3.653 & 0.022 \\
& Kredit Konsumsi & -0.035 & 0.142 & -0.168 & -0.244 & 0.820 \\
& Kredit Modal Kerja & -20.430 & 20.687 & -1.918 & -0.988 & 0.379 \\
& Kredit Investasi & 46.218 & 45.861 & 2.043 & 1.008 & 0.371 \\
\hline
\end{tabular}

a. Dependent Variable: Pendapatan

Sumber : Output SPSS, 2018.

Berdasarkan tabel di atas, diperoleh persamaan regresi linear berganda sebagai berikut: 


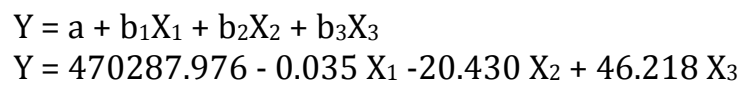

Persamaan regresi di atas dapat di interprestasikan sebagai berikut :

1. Dimana nilai a (constanta) sebesar 470287.976 menunjukkan bahwa jika tidak ada kredit konsumsi, kredit modal kerja, dan kredit investasi, maka pendapatan PT. Bank Bengkulu sebesar Rp. 470.287.976 Nilai pendapatan tersebut dapat diperoleh melalui jasa-jasa perbankan yang diberikan kebada konsumen selain dari kredit.

2. Nilai kredit konsumsi $\left(\mathrm{X}_{1}\right)$ sebesar -0.035 menjukkan pengaruh yang negatif terhadap pendapatan. Artinya, setiap terjadi penurunan Rp. 1 pada kredit konsumsi, serta kredit modal kerja dan kredit investasi tetap. Maka, pendapatan akan mengalami penurunan sebesar Rp. 0.035,--

3. Nilai kredit modal kerja $\left(\mathrm{X}_{2}\right)$ sebesar -20.430 menjukkan pengaruh yang negatif terhadap pendapatan. Artinya, setiap terjadi penurunan Rp. 1 pada kredit modal kerja, serta kredit konsumsi dan kredit investasi tetap. Maka, pendapatan akan mengalami penurunan sebesar Rp. 20.430,--

4. Nilai kredit investasi $\left(\mathrm{X}_{3}\right)$ sebesar 46.218 menjukkan pengaruh yang positif terhadap pendapatan. Artinya, setiap terjadi kenaikan Rp. 1 pada kredit investasi, serta kredit konsumsi dan kredit modal kerja tetap. Maka, pendapatan akan mengalami kenaikan sebesar Rp. 46.218,-.

Berdasarkan persamaan regresi di atas, maka dapat digambarkan bentuk kurva regresi sebagai berikut :

\section{Gambar 2. Kurva Regresi Linear Berganda} Pendapatan

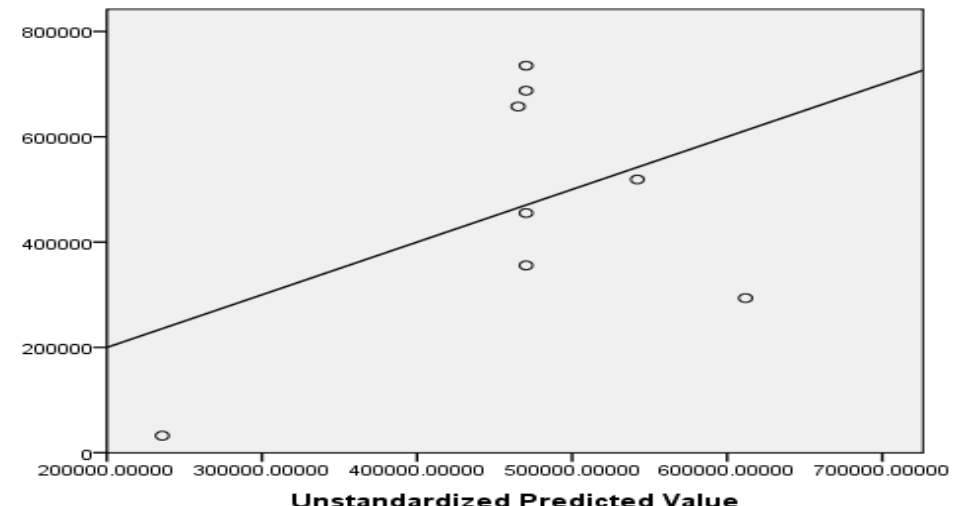

Unstandardized Predicted Value

\section{Hasil Uji Korelasi}

Analisis korelasi sederhana digunakan untuk mengetahui kuat atau lemahnya pengaruh kredit terhadap pendapatan. Hasil analisis korelasi sederhana sebagai berikut:

Tabel 6. Hasil Uji Korelasi Berganda

Correlations

\begin{tabular}{|ll|l|l|l|l|}
\hline & Kredit Konsumsi & Kredit Modal Kerja & Kredit Investasi & Pendapatan \\
\hline Kredit Konsumsi & Korelasi pearson & 1 & $0.736^{*}$ & $0.762^{*}$ & -0.023 \\
& Sig. (2-tailed) & & 0.037 & 0.028 & 0.956 \\
& $\mathrm{~N}$ & 8 & 8 & 8 & 8 \\
\hline Kredit Modal Kerja & Korelasi pearson & $0.736^{*}$ & 1 & $0.973^{* *}$ & -0.052 \\
& Sig. (2-tailed) & 0.037 & 8 & 0.000 & 0.902 \\
& $\mathrm{~N}$ & 8 & 8 & 8 \\
\hline Kredit Investasi & Korelasi pearson & $0.762^{*}$ & $0.973^{* *}$ & 1 & 0.049 \\
& Sig. (2-tailed) & 0.028 & 0.000 & & 0.908 \\
& N & 8 & 8 & 8 & 8 \\
\hline Pendapatan & Korelasi pearson & -0.023 & -0.052 & 0.049 & 1 \\
& Sig. (2-tailed) & 0.956 & 0.902 & 0.908 & 8 \\
\hline
\end{tabular}

*. Correlation is significant at the 0.05 level (2-tailed).

**. Correlation is significant at the 0.01 level (2-tailed).

Sumber : Output SPSS, 2018 
Berdasarkan tabel di atas, hasil analisis korelasi menujukkan bahwa variabel kredit konsumsi $\left(\mathrm{X}_{1}\right)$ mempunyai korelasi yang signifikan terhadap kredit modal kerja $\left(\mathrm{X}_{2}\right)$ dan kredit investasi $\left(\mathrm{X}_{3}\right)$ dengan nilai signifkansi masing-masing sebesar 0.037 dan 0.028 , serta kredit konsumsi $\left(\mathrm{X}_{1}\right)$ tidak mempunyai korelasi yang signifikan terhadap pendapatan (Y) dengan nilai signifikansi sebesar 0.956.

Kredit modal kerja $\left(\mathrm{X}_{2}\right)$ mempunyai korelasi yang signifikan terhadap kredit konsumsi $\left(\mathrm{X}_{1}\right)$ dan kredit investasi $\left(\mathrm{X}_{3}\right)$ dengan tingkat signiifkansi masing-masing sebesar 0.037 dan 0.000, serta kredit modal kerja $\left(\mathrm{X}_{2}\right)$ tidak mempunyai korelasi yang signifikan terhadap pendapatan $(\mathrm{Y})$ dengan tingkat signifikansi sebesar 0.902 .

Kredit investasi $\left(\mathrm{X}_{3}\right)$ mempunyai korelasi yang signifikan terhadap kredit konumsi $\left(\mathrm{X}_{1}\right)$ dan kredit modal kerja $\left(\mathrm{X}_{2}\right)$ dengan tingkat signifikansi masing-masing sebesar 0.028 dan 0.000, serta kredit invesatasi tidak mempunyai korelasi terhadap pendapatan dengan nilai signifikansi sebesar 0.908.

\section{Hasil Uji Koefisien Determinasi $\left(\mathrm{R}^{2}\right)$}

Koefisien determinasi $\left(\mathrm{R}^{2}\right)$ digunakan untuk mengukur seberapa besar kemampuan variabel kredit untuk menjelaskan variabel pendapatan. Nilai $R$ Square berkisar antara 0-1, dimana semakin kecil nilai $R$ Square menunjukkan semakin lemahnya hubungan antar variabel, sebaliknya jika nilai $R$ Square semakin besar maka semakin besar kemampuan variabel independen dalam menjelaskan pengaruh terhadap variabel dependen.

Tabel 7. Hasil Uji Koefisien Determinasi $\left(\mathbf{R}^{2}\right)$

\section{Model Summary}

\begin{tabular}{|l|l|l|l|l|}
\hline Model & R & R Square & Adjusted R Square & Std. Error of the Estimate \\
\hline 1 & $0.453^{\mathrm{a}}$ & 0.205 & -0.391 & 278747.209 \\
\hline
\end{tabular}

a. Predictors: (Constant), Kredit Investasi, Kredit Konsumsi, Kredit Modal Kerja

Sumber: Output SPSS 17, Data Diolah, 2018.

Berdasarkan tabel di atas, diperoleh nilai $R$ Square sebesar 0.205 atau $20.5 \%$ yang berarti pengaruh kredit terhadap pendapatan pada PT. Bank Bengkulu adalah sebesar 20.5\% . Sedangkan 79.5\% dipengaruhi oleh faktor lain yang tidak termasuk dalam penelitian. Kemampuan kredit dalam menjelaskan pengaruhnya terhadap pendapatan sangat kecil.

\section{Uji Hipotesis \\ Uji Statistik t (Uji t)}

Untuk melakukan pengujian hipotesis digunakan uji statistik $\mathrm{t}$ (Uji $\mathrm{t}$ ), pengujian hipotesis digunakan untuk melihat apakah variabel kredit konsumsi $\left(\mathrm{X}_{1}\right)$, kredit modal kerja $\left(\mathrm{X}_{2}\right)$, kredit investasi $\left(\mathrm{X}_{3}\right)$ mempunyai pengaruh terhadap variabel pendapatan (Y). Jika nilai signifikansi $<0,05$ dan nilai $t_{\text {hitung }}>$ ttabel, maka hipotesis $\mathrm{H}_{a}$ dapat diterima, artinya terdapat hubungan yang signifikan antara kredit yang diberikan terhadap pendapatan. Sebaliknya, jika nilai signifikansi $>0,05$ dan nilai $t_{\text {hitung }}<t_{\text {tabel, }}$ maka hipotesis $\mathrm{H}_{0}$ dapat diterima, artinya tidak terdapat hubungan yang signifikan antara kredit yang diberikan terhadap pendapatan. Hasil pengujian hipotesis dapat dilihat pada tabel berikut:

Tabel 8. Hasil Uji Hipotesis t (Uji t)

Coefficients ${ }^{a}$

\begin{tabular}{|c|c|c|c|c|c|c|}
\hline & \multirow[b]{2}{*}{ Model } & \multicolumn{2}{|c|}{ Koefisien Tidak Standar } & \multicolumn{3}{|c|}{ Koefisien Standar } \\
\hline & & B & Std. Error & Beta & $\mathrm{T}$ & Sig. \\
\hline \multirow[t]{4}{*}{1} & (Konstanta) & 470287.976 & 128727.036 & & 3.653 & 0.022 \\
\hline & Kredit Konsumsi & $0-.035$ & 0.142 & $0-.168$ & -0.244 & 0.820 \\
\hline & Kredit Modal Kerja & -20.430 & 20.687 & -1.918 & 0.988 & 0.379 \\
\hline & Kredit Investasi & 46.218 & 45.861 & 2.043 & 1.008 & 0.371 \\
\hline
\end{tabular}

a. Dependent Variable: Pendapatan

Sumber : Output SPSS, 2018. 
Berdasarkan tabel di atas, tingkat signifikansi variabel kredit konsumsi ( $\mathrm{X}_{1}$ ) sebesar 0.820 atau 82.0\% dan berada di atas 0,05 atau 5\%. Sedangkan nilai thitung sebesar -0.244 lebih kecil dari nilai $t_{\text {tabel }}$ 2.446 (terlampir). Jadi, berdasarkan hasil pengujian hipotesis dapat dinyatakan bahwa variabel kredit konsumsi mempunyai pengaruh yang negatif dan tidak signifikan terhadap pendapatan (Y) pada PT. Bank Bengkulu. Artinya, hipotesis $\mathrm{H}_{1}$ dapat diterima dan menolak hipotesis $\mathrm{Ha}_{1}$.

Pengujian variabel kredit modal kerja $\left(\mathrm{X}_{2}\right)$ menunjukkan hasil bahwa tingkat signifikansi sebesar 0.379 atau $37.9 \%$ berada di atas 0.05 atau $5 \%$ dan nilai thitung $0.988<$ tabel 2.466 . Jadi, berdasarkan hasil pengujian hipotesis dapat dinyatakan bahwa variabel kredit modal kerja $\left(\mathrm{X}_{2}\right)$ berpengaruh negatif dan tidak signifikan terhadap pendapatan $(\mathrm{Y})$. Artinya, hipotesis $\mathrm{H}_{2}$ diterima dan menolak hipotesis $\mathrm{Ha}_{2}$.

Hasil pengujian variabel kredit investasi $\left(\mathrm{X}_{3}\right)$ menunjukkan pengaruh yang positif dan tidak signifikan terhadap pendapatan dengan tingkat signifikansi sebesar 0.371 atau $37.1 \%$ berada di atas $5 \%$, serta nilai thitung $1.008<t_{\text {tabel }} 2.466$. Jadi, berdasarkan hasil pengujian hipotesis dapat dinyatakan bahwa variabel kredit investasi $\left(\mathrm{X}_{3}\right)$ berpengaruh positif dan tidak signifikan terhadap pendapatan (Y). Artinya, hipotesis $\mathrm{H}_{3}$ diterima dan menolak $\mathrm{Ha}$.

\section{Uji Statistik F (Uji F)}

Uji statistik F digunakan untuk melihat pengaruh variabel independen terhadap variabel dependen secara simultan atau secara bersama-sama. Hasil uji F adalah sebagai berikut:

Table 9. Hasil Uji Hipotesis F (Uji F)

ANOVA $^{\mathbf{b}}$

\begin{tabular}{|ll|l|l|l|l|l|}
\hline Model & & Sum of Squares & df & Mean Square & F & Sig. \\
\hline 1 & Regression & 8.018 & 3 & 2.673 & 0.344 & $0.796^{\mathrm{a}}$ \\
& Residual & 3.108 & 4 & 7.770 & & \\
& Total & 3.910 & 7 & & & \\
\hline
\end{tabular}

a. Predictors: (Constant), Kredit Investasi, Kredit Konsumsi, Kredit Modal Kerja

b. Dependent Variable: Pendapatan

Sumber : Output SPSS, 2018.

Berdasarkan tabel di atas, hasil uji F menunjukkan bahwa secara simultan variabel kredit konsumsi $\left(\mathrm{X}_{1}\right)$, kredit modal kerja $\left(\mathrm{X}_{2}\right)$, kredit investasi $\left(\mathrm{X}_{3}\right)$ tidak berpengaruh signifikan terhadap pendapatan (Y). nilai signifikansi yang diperoleh adalah sebesar 0.796 atau 79.6\% lebih besar dari 5\%, serta nilai Fhitung $0.344<\mathrm{F}_{\text {tabel }}$ 5.786. Jadi, dapat disimpulkan bahwa variabel kredit konsumsi $\left(\mathrm{X}_{1}\right)$, kredit modal kerja $\left(\mathrm{X}_{2}\right)$, kredit investasi $\left(\mathrm{X}_{3}\right)$ tidak

\section{Pembahasan} berpengaruh signifikan terhadap pendapatan (Y). Artinya, menolak $\mathrm{Ha}_{4}$ dan menerima $\mathrm{H}_{4}$.

Penelitian ini menggunakan teknik analisis regresi linear berganda dengan metode pengumpulan data dengan sistem penelusuran literatur atau data yang sudah tersedia, dalam hal ini data sekunder berupa laporan keuangan PT. Bank Bengkulu periode tahun 2010 sampai dengan tahun 2017. Dari hasil penelitian yang dilakukan dapat dilihat jumlah kredit sebagai variabel independen mempunyai pengaruh terhadap pendapatan sebagai variabel dependen. Berdasarkan hasil penelitian, diperoleh persamaan regresi linear sederhana yaitu $\mathrm{Y}=470287.976-0.035 \mathrm{X}_{1}-20.430 \mathrm{X}_{2}+46.218 \mathrm{X}_{3}$, nilai a (constanta) sebesar 470.028 yang artinya jika nilai kredit konsumsi, kredit modal kerja, kredit investasi 0 maka nilai pendapatan Rp. 470.028. Sedangkan nilai $b_{1}$ sebesar -0.035 menunjukkan bahwa setiap adanya penurunan Rp. 1,- pada kredit konsumsi (X $\mathrm{X}_{1}$ ) akan dapat menurunkan pendapatan (Y) sebesar Rp. 0.035. nilai $b_{2}$ sebesar -20.430 menunjukkan bahwa setiap penurunan Rp. 1,- pada kredit modal kerja $\left(\mathrm{X}_{2}\right)$ akan dapat menurunkan pendapatan (Y) sebesar Rp. 20.430. Sedangkan nilai b3 sebesar 46.218 menunjukkan bahwa setiap kenaikan Rp. 1,- pada kredit investasi $\left(\mathrm{X}_{3}\right)$ akan meningkatkan pendapatan (Y) sebesar Rp. 46.218.

Hasil analisis korelasi sederhana ( $\mathrm{r}$ ) menunjukkan tingkat pengaruh antara kredit konsumsi $\left(\mathrm{X}_{1}\right)$, kredit modal kerja $\left(\mathrm{X}_{2}\right)$, dan kredit investasi $\left(\mathrm{X}_{3}\right)$ terhadap pendapatan sebesar 0.205. Artinya, pengaruh antara kredit terhadap pendapatan sangat rendah. Kredit hanya mampu menjelaskan pengaruh nya terhadap pendapatan sebesar 20,5\%, sedangkan 75,5\% dapat dipengaruh oleh factor lain.

Hasil pengujian hipotesis dengan menggunakan uji statistik t (uji t) menunjukkan hasil bahwa kredit konsmsi $\left(\mathrm{X}_{1}\right)$ berpengaruh negatif dan tidak sinifikan terhadap pendapatan (Y), hal ini dibuktikan dengan nilai signifikansi variabel kredit konsumsi sebesar $0.820>0.05$ dan nilai thitung sebesar $-0.244<$ 2.446 ttabel. Maka, berdasarkan hasil pengujian hipotesis tersebut dapat menerima hipotesis $\mathrm{H}_{1} \mathrm{yang}$ 
menyatakan bahwa kredit konsumsi tidak mempunyai pengaruh yang positif signifikan terhadap pendapatan.

Hasil pengujian hipotesis kredit modal kerja $\left(\mathrm{X}_{2}\right)$ terhadap pendapatan menunjukkan hasil bahwa kredit modal kerja berpengaruh negative dan tidak signifikan terhadap pendapatan dengan tingkat signifikansi sebesar 0.379 atau $37.9 \%$ dan nila thitung $-0.988<t_{\text {tabel }} 2.446$. Berdasarkan hasil pengujian tersebut, maka dapat dinyatakan bahwa kredit modal kerja berpengaruh negatif dan tidak signifikan terhadap pendapatan. Artinya, keputusan yang diambil dapat menerima $\mathrm{H}_{2}$ dan menolak $\mathrm{Ha}_{2}$.

Hasil pengujian hipotesis variabel kredit investasi $\left(\mathrm{X}_{3}\right)$ menunjukkan hasil bahwa kredit investasi berpengaruh positif dan tidak signifikan terhadap pendapatan dengan tingkat signifikansi sebesar 0.371 atau $37.1 \%$ dengan nilai thitung $1.008<t_{\text {tabel }} 2.446$. Hasil pengujian terse but menyatakan bahwa kredit investasi berpengaruh positif dan tidak signifikan terhadap pendapatan, maka hipotesis $\mathrm{H}_{3}$ diterima dan menolah hipotesis $\mathrm{Ha}_{3}$.

Kredit merupakan salah satu aktiva produktif bank yang dapat menyumbangkan pendapatan, dari berbagai macam sumber yang bisa menghasilkan pendapatan hanya kredit yang diberikan kepada nasabah yang dapat menyumbang pendapatan paling besar. Karena, kredit merupakan bisnis unggulan perbankan dalam melayani kebutuhan keuangan konsumen. Semakin besar jumlah kredit yang diberikan, maka besar kesempatan untuk memperoleh pendapatan. Rata-rata kredit konsumsi yang diberikan oleh PT. Bank Bengkulu dari tahun 2010 sampai dengan tahun 2017 adalah sebesar Rp. 695.954,-. Rata-rata kredit modal kerja dari tahun 2010 sampai tahun 2017 sebesar Rp. 17.354,-. Sedangkan rata-rata kredit investasi adalah sebesar Rp. 8.123,-. Serta rata-rata pendapatan yang diperoleh setiap tahunnya dari tahun 2010 sampai dengan tahun 2017 adalah sebesar Rp. 466.986,-. Pertumbuhan angka kredit yang diberikan oleh PT. Bank Bengkulu ini sejalan dengan pendapatan yang diperoleh.

\section{Kesimpulan}

Berdasarkan hasil penelitian dan pembahasan mengenai analisis pengaruh kredit yang diberikan terhadap pendapatan pada PT. Bank Bengkulu dengan menggunakan data laporan keuangan tahun 2010 sampai dengan tahun 2017 dapat disimpulkan sebagai berikut :

1. Hasil pengujian regresi linear sederhana memperoleh persamaan regresi $Y=470287.976-0.035 \mathrm{X}_{1}-$ $20.430 \mathrm{X}_{2}+46.218 \mathrm{X}_{3}$, yang artinya jika nilai kredit konsumsi, kredit modal kerja, kredit investasi 0 maka nilai pendapatan sebesar Rp.470.287. dan jika terjadi penurunan kredit konsumsi sebesar Rp. 1., maka pendapatan akan menurun sebesar Rp. 0.035,- Jika kredit modal kerja mengalami penurunan sebesar Rp. 1,-, maka akan terjadi penurunan nilai pendapatan sebesar Rp. 20.430,- serta jika nilai kredit investasi mengalami peningkatan sebesar Rp. 1,- maka pendapatan akan mengalami peningkatan sebesar Rp. 46.218,-. Persamaan tersebut menunjukkan hubungan yang positif dan negatif antara kredit terhadap pendapatan.

2. Hasil pengujian koefisien determinasi $\left(\mathrm{R}^{2}\right)$ menunjukkan nilai $R$ Square sebesar 0.205 . Artinya, kredit mempunyai pengaruh $20.5 \%$ terhadap pendapatan. Sedangkan $75.5 \%$ dipengaruhi oleh faktor lain yang tidak diteliti.

3. Hasil pengujian hipotesis dengan uji statistik $t$ menujukkan bahwa kredit konsumsi $\left(\mathrm{X}_{1}\right)$ tidak mempunyai pengaruh yang signifikan terhadap pendapatan dengan tingkat signifikan sebesar $0.820>$ 0.05 dan nilai thitung $-0.244<2.446$ tabel. Maka, pernyataan hipotesis $\mathrm{H}_{1}$ diterima dan menolak hipotesis $\mathrm{Ha}_{1}$. Hasil pengujian hipotesis variabel kredit modal kerja $\left(\mathrm{X}_{3}\right)$ menunjukkan hasil bahwa kredit modal kerja berpengaruh negatif dan tidak signifikan terhadap pendapatan dengan tingkat signifikan sebesar $0.379>0.05$ dan nilai thitung $-0.988<2.446$ tabel . Maka, menerima hipotesis $\mathrm{H}_{2}$ dan menolak hipotesis $\mathrm{Ha}_{2}$. Sedangkan hasil pengujian hipotesis variabel kredit investasi $\left(\mathrm{X}_{3}\right)$ menunjukkan hasil pengaruh yang positif dan tidak signifikan terhadap pendapatan dengan tingkat signifikan sebesar $0.371>0.05$ dan nilai thitung $1.008<2.446$ tabel. Maka, hipotesis $\mathrm{H}_{3}$ diterima dan menolak hipoteis $\mathrm{Ha}_{3}$.

4. Hasil pengujian secara simultan atau uji F menunjukkan bahwa secara bersama-sama variabel kredit konsumsi, kredit modal kerja, kredit investasi tidak berpengaruh signfikan terhadap pendapatan dengan tingkat signifikansi sebesar 0.796 dan nilai Fhitung $0.344<$ Ftabel 5.786. Maka, hipotesis $\mathrm{H}_{4}$ diterima dan menolak Ha4.

\section{Saran}

1. Manajemen PT. Bank Bengkulu harus dapat mempertahankan kualitas kredit yang diberikan kepada nasabah agar tidak terjadinya kredit bermasalah yang dapat mengakibatkan kerugian.

2. Dalam pemberian kredit kepada calon debitur, manajemen PT. Bank Bengkulu harus memperhatikan prinsip-prinsip 5 C (character, capacity, capital, collateral, condition of economy). 
3. Manajemen PT. Bank Bengkulu harus terus dapat meningkatkan jumlah kredit yang diberikan agar perolehan pendapatan juga meningkat sehingga dapat memberikan kontibusi yang besar terhadap pertumbuhan bisnis perbankan.

4. PT. Bank Bengkulu harus terus dapat bersaing secara nasional dengan terus memberikan inovasiinovasi dan terobosan yang baik untuk kemajuan bisnis perbankan.

\section{DAFTAR PUSTAKA}

Absudiyah, San.2013. Analisis Pengaruh Pemberian Kredit Usaha Rakyat (KUR) Terhadap Pendapatan Pedagang Kecil Pada PT. Bank Rakyat Indonesia (persero)Cabang Curup. Skripsi : Universitas Dehasen Bengkulu .Tidak Di Publikasikan.

Andayani, Suci. Malinda, Yola. Putri, Yosi Eka. 2014. Pengaruh Penyaluran Kredit Terhadap Pendapatan Operasional Bank (Studi Kasus Pada Bank Nagari Cabang Pasar Raya Padang). Jurnal : STKIP PGRI Sumatera Barat.

Budisusanto, Totok dan Nuritomo. Bank dan Lembaga Keuangan Lainnya, Edisi 3. Jakarta : Salemba Empat.

Erhans. 2010. Akuntansi Berdasarkan Prinsip Akuntansi di Indonesia. Jakarta : PT. Ercontara Rajawali.

Hasan, M Iqbal. 2013. Pokok-Pokok Materi Staistik 1. Jakarta : Bumi Aksara.

Hery. 2016. Analisis Laporan Keuangan, Integrated and Comprehensive Edition. Jakarta : PT. Grasindo.

Irham, Fahmi. 2014. Analisis Laporan Keuangan. Bandung : Alfabeta.

Ismail. 2010. Akuntansi Bank, Teori dan Aplikasi Dalam Rupiah, Edisi Revisi. Jakarta : Prenadamedia Group.

Jati, Dica Suci Enggar. 2015. Pengaruh Pemberian Kredit Modal Kerja Terhadap Tingkat Pendapatan Usaha Kecil dan Menengah (UKM) Pada PT. Bank Pembiayaan Rakyat Syariah (BPRS) Margariski Bahagia Bantul. Skripsi : Universitas Negeri Sunan Kalijaga Yogyakarta.

Kasmir. 2014. Manajemen Perbankan. Edisi Revisi. Jakarta : PT. Raja Grafindo Persada. 2016. Dasar-Dasar Perbankan, Edisi Revisi. Jakarta : Rajawali Pers.

Kasiram, Mohammad. 2008. Metode Penelitian Kualitatif-Kuantitatif. Malang : UIN Malang Press.

Kamaludin. 2011. Manajemen Keuangan "Konsep Dasar dan Penerapan”. Bandung : PT. Maju Mundur.

Rivai, Veithzal. 2005. Manajemen Dana Bank. Bandung : Pionir Jaya.

Riadi, Edi. 2016. Statistika Penelitian, Analisis Manual dan IBM SPSS. Yogyakarta : Andi.

Surat Edaran Bank Indonesia Nomor 7/3/DPNP tahun 2005 tentang Sistem Penilaian Kesehatan Bank Umum. Jakarta : Bank Indonesia.

Taswan. 2017. Akuntansi Perbankan, Transaksi Dalam Valuta Rupiah. Yogyakarta : UPP STIM YKPN.

Undang-Undang Republik Indonesia Nomor 10 tahun 1998 tentang Perubahan Undang-Undang Nomor 7 tahun 1992 tentang Perbankan. Jakarta : Bank Indonesia.

Wijaya, Toni. 2011. Cepat Menguasai SPSS 19. Yogyakarta : Cahaya Atma. 